\title{
Management of Seed Borne Pathogens of Rice
}

\author{
Mohammad Waris, Pagoti Hemalatha*, M.K. Mishra and Abhaya Kumar Kar \\ Department of Plant Pathology, College of Agriculture, Orissa university of Agriculture and \\ technology, Bhubaneswar - 751 003, Odisha, India \\ *Corresponding author
}

\section{A B S T R A C T}

\begin{abstract}
Most of the rice diseases are transmitted by seeds which are the important limiting factor getting good quality seeds and good yield. Stored and freshly harvested rice seed of different varieties were collected from Agricultural farm of Orissa University of Agriculture and Technology, Bhubaneswar, Odisha to study the association of different fungal pathogens. The seeds were graded on the basis of intensity of discoloration. Among nine plant products evaluated against the pathogenic fungi Fusarium fujikuroi, Curvurlaria lunata, Helminthosporium oryzae, garlic extract alone and in combination with datura and neem leaf extract completely inhibited the growth of the fungi at 10\% and $20 \%$ concentration. The biocontrol agents Trichoderma viride and Bacillus subtilis inhibited the growth of $F$. fujikuroi up to $78.11 \%$ and $78.7 \%$ respectively. Pseudomonas fluorescens inhibited $74.06 \%$ radial growth of $H$. oryzae which was more than B. subtilis $(22.66 \%$ inhibition). 52.4\% growth reduction was found by $T$. viride against $C$. lunata followed by P. fluorescens (51.8\% reduction). Propiconazol $0.1 \%$, Carbendazim+Mancozeb0.1\%, Carboxin+Thiram $0.2 \%$ Tebuconazol $0.1 \%$ and copper oxychloride $0.3 \%$ completely inhibited the growth of all three pathogens.
\end{abstract}

\section{Introduction}

Rice (Oryza sativa L.) is one of the most important staple foods for more than half of the world's population (IRRI, 2006) and influences the livelihoods and economies of several billion people, and is grown in almost all the tropical and subtropical regions of the world.

Rice is cultivated in an area of 165 million hectares, the world rice production is now touching to 744.4 million tonnes (496.4 million tonnes, milled basis), (FAO 2014).
Seed is the vital input in Agriculture. Good quality and viable seed is required for healthy and synchronous seedling which is prerequisite for successful crop establishment and uniform crop growth and development and finally the yield.

The three major aspects of seed quality are, a) genetic and physical purity, b) high germination percentage and vigor, and c) free from seed-borne diseases and insects (Seshu and Dadlani, 1988). Moreover, seeds of rice are imported and being sold without testing of health. Therefore, it is necessary to understand 
the problem properly which affect the seed germination and take necessary steps need to be taken to overcome this huge amount of loss.

\section{Materials and Methods}

\section{Collection of seed samples}

Both stored and freshly harvested seed of different rice varieties were collected from Central Agricultural Research Farm, College of Agriculture, O.U.A.T, Bhubaneswar, Odisha during the Kharif season of 2014 and 2015.

Effect of various plant extracts on the growth inhibition of rice seed mycoflora

All the extracts were centrifuged at $10000 \mathrm{rpm}$ for 10 minutes except garlic at $4000 \mathrm{rpm}$ and the extracts were regarded as $100 \%$ and adjusted to different concentration as per need.

\section{Poisoned food technique}

The bio-efficacy of plant extracts were evaluated by poisoned food technique (Nene and Thapliyal, 1973). Ten, twenty ml of crude extracts were mixed with 90 and $80 \mathrm{ml}$ of molten potato dextrose agar medium so as to get $10 \%$ and $20 \%$ concentration respectively. Control was maintained without any plant extract.

The poisoned media was sterilized by autoclaving at 10 psi for 25 minutes. Twenty $\mathrm{ml}$ of media was poured into petri dish and allowed to solidify. Five mm culture disc was put on the middle of the solidified Petri Plate s. All the Plates were incubated at room temperature. Mycelia growth measurement was taken when maximum growth was observed in control plate. The efficacy was expressed as percentage inhibition of mycelia growth over control.
$\mathrm{I}=\mathrm{C}-\mathrm{T} / \mathrm{C} \times 100$ (Vincent, 1947) $\mathrm{I}=$ Percent inhibition $\mathrm{C}=$ Radial growth in control $\mathrm{T}=$ Radial growth in treatment

In-vitro Effect of various biocontrol agents on the growth inhibition of rice seed mycoflora

The efficacy of biocontrol agents were tested against casual organism by dual culture technique. Biocontrol agents like Trichoderma viride, Trichoderma hamatum, and $T$. harzianum, Pseudomonas fluorescens and Bacillus subtillis were tested against the isolated fungi by using dual culture technique.

In-vitro testing of various fungicides against seed borne pathogens of rice

Required amount of fungicides were added to pre sterilized potato dextrose agar medium. Twenty $\mathrm{ml}$ of poisoned medium was poured into sterilized Petri dishes. Mycelial discs of five $\mathrm{mm}$ from actively growing zone of ten days old culture were inoculated into each Plate and placed at the centre of Petri plate. Control was maintained without adding any fungicide. Each treatment was replicated thrice. The Plate $\mathrm{s}$ were incubated at $27 \pm 1^{\circ} \mathrm{C}$ temperature and radial growth of fungal mycelium was measured from both direction and radial growth was calculated. The data were analyzed statistically and efficacy of fungicide was expressed as percentage of inhibition of mycelia growth over control. The formula (Vincent, 1947) was used for calculation as mention above.

\section{Results and Discussion}

Efficacy of various plant extracts and their combination on the growth inhibition of different rice seed mycoflora

Nine plant extracts including combination of (garlic clove, datura and neem leaf extracts) 
and neem oil were used for management of three seed borne pathogens of rice viz., $F$. fujikuroi, $H$. oryzae and $C$. lunata in the laboratory condition (Fig. 1a and b).

\section{Efficacy of phyto extracts on the growth inhibition of $F$. fujikuroi on rice seed}

The result indicated that there was significant differences among all the tested plant extracts and oil in both the $10 \%$ and $20 \%$ concentration were used against the pathogens. Garlic bulb extract alone and combination with datura and neem leaves extracts completely inhibited the radial growth of test pathogen in both 10 and $20 \%$ concentration.

Efficacy of phyto extracts on the growth inhibition of $\mathrm{H}$. oryzae on rice seed

All the plant extract in both the concentration showed growth reduction of $H$. oryzae. Here also garlic bulb and combination with Datura and Neem leaves extracts completely inhibited the growth resulting $100 \%$ control. Neem leaves extracts $(10 \%)$ induce least growth inhibition (4.58\%) fallowed by onion bulb extract (10.68) Datura, Neem oil and Karanj, Turmeric exhibited similar pattern in controlling $F$. fujikuroi. But in $20 \%$ concentration datura, onion and neem oil exhibited similar pattern) (Table 1).

Onion bulb extracts and mint leaf extract, showed similar growth pattern with control treatment in $10 \%$ concentration. Datura, onion, neem oil and turmeric rhizome extracts exhibited similar growth inhibition in $20 \%$ concentration.

Efficacy of phyto extracts on the growth inhibition of $C$. lunata on rice seed

Significant differences were also observed among all plant extracts in reducing the radial growth of $C$. lunata in both $10 \%$ and $20 \%$ concentration. Here also garlic alone and combination with datura and neem leaf extracts control the test pathogen completely (100\%). Mint, neem leaf and onion bulb extracts all (10\% concentration) grew in similar way as that of control Plate s. There was no significant difference observed in growth inhibition of the test pathogen among neem oil $45.47 \%$ and turmeric rhizome extracts $44.55 \%$ at (10\%) concentration (Table 2).

The result indicated that there was significant differences among all the tested plant extracts and oil in both the $10 \%$ and $20 \%$ concentration were used against the pathogens. Garlic bulb extract alone and combination with datura and neem leaves extracts completely inhibited the radial growth of test pathogen in both 10 and $20 \%$ concentration.

Neem leaf extract (10\%) recorded less growth inhibition $(4.58 \%)$ followed by Onion bulb extract 10.68\%. Asadi and Behroozin (1987) found similar result of growth inhibition of $F$. solani, F.oxysporum and F. acuminatum using Garlic bulb extract and Garlic bulb extract with datura and neem leaves completely inhibited the growth of $H$. oryzae resulting $100 \%$ control.

Onion bulb and Mint leaf extract showed similar growth pattern with control in $10 \%$ concentration. Lalitha et al., (2014) conducted in vitro evaluation of essential oils of $P$. nigram, S. album against different seed borne pathogens and found $100 \%$ inhibition in radial growth of Bipolaris oryzae. In the current study $55.60 \%$ inhibition in radial growth was observed against $H$. oryzae (B. oryzae). The growth of Curvularia lunata was completely reduced by garlic bulb extract alone and combination with datura and neem leaf in both 10 and $20 \%$ concentration. 
Efficacy of bio control agents against rice seed mycoflora

Efficacy of five bio control agents comprising Trichoderma viride Trichoderma harzainum, Trichoderma hamatum, Pseudomonas fluorescens and Basillus subtilis were evaluated against three seed mycoflora i.e. $F$. fujikuroi, $H$. oryzae and $C$. lunata in dual culture method. Trichoderma viride and Bacillus subtilis inhibited the growth $F$. fujikuroi up to $78.11 \%$ and $78.72 \%$ respectively. $T$. hamatum reduced the radial growth of $F$. fujikuroi (66.47\%) which was less than T. viride. Pseudomonas fluorescens recorded highest $(74.06 \%)$ inhibiting radial growth of $H$. oryzae which was more efficacious than Bacillus sabtilis $(22.66 \%$ inhibition). Among three Trichoderma sp., T. harzianum had less bio control activity (27.1\% reduction) with $T$. hamatum the highest (67.76\% reduction). All the five bio control agents express reduced efficacy against $C$. lunata. Maximum $52.41 \%$ growth reduction was found by $T$. viride fallowed by $P$. fluorescens (51.8\% reduction). Other three bio agents reduced the radial growth below 50\% (Figure 2 and Table 3 ).

Bio efficacy of five bio control agents Trichoderma viride, Trichoderma harzianum, Trichoderma hamatum, Pseudomonas fluorescens and Bacillus subtilis were evaluated against three fungi i.e Fusarium fujikuroi, Helminthosporium oryzae and Curvularia lunata in dual culture method. Trichoderma viride and Bacillus subtillis inhibited the growth of Fusarium fujikuroi up to $78.11 \%$ and $78.7 \%$ respectively. $P$. fluorescens inhibited $74.6 \%$ radial growth of H. oryzae which was more than Bacillus subtilis (22.66\% inhibition).

In inhibiting the radial growth of $H$. oryzae, among three Trichoderma sp., T. hamatum reduced up to $67.76 \%$ radial growth. $T$. viride caused 52.4\% reduction of mycelial growth followed Pseudomonas fluorescens (51.8\%reduction) against Curvularia lunata. Srinivas and Ramkrishan (2005) tested bio control effect of $T$. viride against seed borne pathogen of rice reduced radial growth of the pathogens.

Selvarraj and Anamalai (2015) used two species of Trichoderma against Sarochladium oryzae and found $96 \%$ inhibition of radial growth by $T$. harzianum. Halgearkar et al., (2014) recorded significant suppression of mycelial growth of Helminthosporium oryzae (D. oryzae) by $T$. viride and T. harzianum. $\mathrm{He}$ also reported $97.77 \%$ inhibition by Bacillus subtilis against $C$. lunata fallowed $T$. viride. In the current study also Bacillus subtilis induced $42.41 \%$ growth inhibition.

\section{Efficacy of various fungicides against the seed borne pathogens of rice}

A total numbers of 12 different fungicides were tested against the radial growth of $F$. fujikuroi, $H$. oryzae and C. lunata for their efficacy in-vitro condition.

\section{Effect on $F$. fujikuroi}

It was evident from the data all the chemicals showed significantly different growth inhibition as compare to control.

Carbendazim $0.1 \%$, propeconazole $0.1 \%$, copper oxy chloride $0.3 \%$, carbendazim + mancozeb $0.1 \%$ carboxin thiram $0.2 \%$ and tebuconazole $0.1 \%$ completely inhibited the growth of $F$. fujikuroi exhibiting $100 \%$ growth inhibiting over control.

Thiophenate methyl $0.1 \%$ and hexaconazole $0.2 \%$ also reduced the growth of test pathogens to $94.4 \%$ and $89.04 \%$ respectively. Other fungicides were also good in comparison to control (Table 4 and Figure 3a). 
Table.1 Effect of various plant extracts (10\%) on the growth inhibition of rice seed mycoflora

\begin{tabular}{|c|c|c|c|c|c|c|}
\hline \multirow[t]{2}{*}{ Treatments } & \multirow[b]{2}{*}{ Fusarium } & \multirow[b]{2}{*}{$\%$} & \multicolumn{2}{|c|}{ Radial growth (mm) } & \multirow[b]{2}{*}{ Curvulari } & \multirow[b]{2}{*}{$\%$} \\
\hline & & & H. oryzae & $\%$ & & \\
\hline & fujikuroi & inhibition & & Inhibition & a lunata & inhibition \\
\hline & & over & & Over & & over \\
\hline & & control & & Control & & control \\
\hline \multirow[t]{2}{*}{ Datura } & 35.83 & 53.16 & 35.83 & 58.58 & 29.33 & 59.17 \\
\hline & $(6.02)$ & & $(6.02)$ & & $(5.45)$ & \\
\hline \multirow[t]{2}{*}{ Garlic bulb } & 0.00 & 100 & 0.00 & 100 & 0.00 & 100 \\
\hline & $(0.71)$ & & $(0.71)$ & & $(0.71)$ & \\
\hline \multirow[t]{2}{*}{ Mint } & 63.67 & 16.77 & 85.00 & 1.73 & 68 & 5.33 \\
\hline & (8.00) & & $(9.24)$ & & $(8.40)$ & \\
\hline \multirow[t]{2}{*}{ Neem leaves } & 73.00 & 4.58 & 71.67 & 17.14 & 70.0 & 2.55 \\
\hline & $(8.57)$ & & $(8.49)$ & & $(8.40)$ & \\
\hline \multirow[t]{2}{*}{ Onion bulb } & 68.33 & 10.68 & 84.67 & 2.12 & 69.17 & 3.70 \\
\hline & $(8.30)$ & & $(9.23)$ & & $(8.33)$ & \\
\hline \multirow[t]{2}{*}{ Karanj leaves } & 59.00 & 22.88 & 70.67 & 18.30 & 53.00 & 26.21 \\
\hline & (7.65) & & $(8.43)$ & & $(7.26)$ & \\
\hline \multirow[t]{2}{*}{ Neem oil } & 37.50 & 50.98 & 55.33 & 36.03 & 39.17 & 45.47 \\
\hline & $(6.09)$ & & (7.46) & & $(6.29)$ & \\
\hline Turmeric & 52.17 & 31.80 & 45.83 & 47.02 & 39.83 & 44.55 \\
\hline Rhizomes & (7.25) & & $(6.81)$ & & (6.34) & \\
\hline Garlic bulb+ & 0.00 & 100 & 0.00 & 100 & 0.00 & 100 \\
\hline neem + datura & $(0.71)$ & & $(0.71)$ & & $(0.71)$ & \\
\hline \multirow[t]{2}{*}{ Control } & 76.50 & - & 86.50 & - & 71.83 & - \\
\hline & (8.77) & & $(9.33)$ & & $(8.49)$ & \\
\hline $\operatorname{SEm}( \pm)$ & 0.32 & & 0.15 & & 0.15 & \\
\hline $\mathrm{CD}(5 \%)$ & 0.97 & & 0.47 & & 0.45 & \\
\hline
\end{tabular}

*Figures in the parentheses indicates $\sqrt{ }+0.5$ transform values 
Table.2 Effect of various plant extracts (20\%) on the growth inhibition of rice seed mycoflora

\begin{tabular}{|c|c|c|c|c|c|c|}
\hline \multirow[t]{5}{*}{ Treatments } & \multirow{3}{*}{$\begin{array}{l}\text { Fusarium } \\
\text { fujikuroi }\end{array}$} & & \multicolumn{2}{|c|}{ ORadial growth $(\mathrm{mm})$} & \multirow[b]{2}{*}{ Curvulari } & \multirow[b]{2}{*}{$\%$} \\
\hline & & $\%$ & H. oryzae & $\%$ & & \\
\hline & & inhibition & & inhibition & a lunata & inhibition \\
\hline & & over & & over & & over \\
\hline & & control & & control & & control \\
\hline \multirow[t]{2}{*}{ Datura } & 27.17 & 64.79 & 27.33 & 61.69 & 21.00 & 71.94 \\
\hline & $(5.25)$ & & $(5.24)$ & & $(4.63)$ & \\
\hline \multirow[t]{2}{*}{ Garlic bulb } & 0.00 & 100 & 0.00 & 100 & 0.00 & 100 \\
\hline & $(0.71)$ & & $(0.71)$ & & $(0.71)$ & \\
\hline \multirow[t]{2}{*}{ Mint } & 61.33 & 20.53 & 63.17 & 11.44 & 67.67 & 9.57 \\
\hline & (7.86) & & (7.98) & & $(8.25)$ & \\
\hline \multirow[t]{2}{*}{ Neem leaves } & 62.67 & 18.79 & 37.33 & 46.67 & 59.00 & 21.15 \\
\hline & (7.91) & & (6.13) & & (7.71) & \\
\hline \multirow{2}{*}{ Onion bulb } & 27.83 & 63.94 & 27.83 & 60.98 & 39.67 & 46.99 \\
\hline & $(5.30)$ & & $(5.31)$ & & $(6.31)$ & \\
\hline \multirow[t]{2}{*}{ Karanj leaves } & 14.67 & 80.99 & 23.67 & 66.82 & 49.83 & 33.41 \\
\hline & $(3.87)$ & & $(4.89)$ & & (7.09) & \\
\hline \multirow[t]{2}{*}{ Neem oil } & 33.33 & 56.81 & 31.67 & 55.60 & 27.33 & 63.48 \\
\hline & $(5.79)$ & & $(5.65)$ & & $(5.26)$ & \\
\hline Turmeric & 44.67 & 42.11 & 31.17 & 56.30 & 21.50 & 71.27 \\
\hline Rhizomes & (6.69) & & $(5.62)$ & & $(4.69)$ & \\
\hline Garlic bulb+ & 0.00 & 100 & 0.00 & 100 & 0.00 & 100 \\
\hline neem + datura & $(0.71$ & & $(0.71)$ & & $(0.71)$ & \\
\hline \multirow[t]{2}{*}{ Control } & 77.17 & - & 71.33 & - & 74.83 & - \\
\hline & $(8.81)$ & & $(8.47)$ & & $(8.68)$ & \\
\hline $\operatorname{SEm}( \pm)$ & 0.29 & & 0.28 & & 0.22 & \\
\hline $\mathrm{CD}(5 \%)$ & 0.87 & & 0.85 & & 0.66 & \\
\hline
\end{tabular}

*Figures in the parentheses indicates $\sqrt{ }+0.5$ transform values

Table.3 Effect of various biocontrol agents on the growth inhibition of rice seed mycoflora

\begin{tabular}{|l|l|l|l|l|l|l|l|}
\hline & Treatments & \multicolumn{5}{|l|}{ Radial growth (mm) } & \\
\hline & & F. fujikuroi & \% inhibition & H. oryzae & \% inhibition & C. lunata & \% inhibition \\
\hline T1 & Control & 88.5 & - & 71.33 & - & 90.00 & - \\
\hline T2 & Trichoderma & 19.37 & 78.11 & 46.17 & 35.27 & 42.83 & 52.41 \\
\hline & Viride & & & & & & \\
\hline T3 & T. harzianum & 41.67 & 52.92 & 52.0 & 27.10 & 48.50 & 46.11 \\
\hline T4 & T. hamatum & 29.67 & 66.47 & 23.0 & 67.76 & 52.83 & 41.30 \\
\hline T5 & $\begin{array}{l}\text { P. } \\
\text { fluorescens }\end{array}$ & 39.00 & 55.93 & 18.50 & 74.06 & 43.33 & 51.86 \\
\hline T6 & Bacillus & 18.83 & 78.72 & 55.17 & 22.66 & 51.83 & 42.41 \\
\hline & Subtilis & & & & & & \\
\hline
\end{tabular}


Table.4 Effect of various fungicides on the growth inhibition of rice seed mycoflora

\begin{tabular}{|c|c|c|c|c|c|c|c|}
\hline \multirow{2}{*}{$\begin{array}{l}\text { Treatment } \\
\mathrm{S}\end{array}$} & \multirow[t]{2}{*}{ Dosage } & \multirow[b]{2}{*}{$F$. } & \multirow[b]{2}{*}{$\%$} & \multicolumn{2}{|c|}{ Radial growth (mm) } & \multirow[b]{2}{*}{ C. } & \multirow[b]{2}{*}{$\%$ inhibition } \\
\hline & & & & H. oryzae & $\%$ & & \\
\hline & & fujikuroi & Inhibition & & inhibition & lunata & over control \\
\hline & & & over control & & over control & & \\
\hline \multirow[t]{2}{*}{$* \mathrm{~T} 1$} & $0.3 \%$ & 18.20 & 74.72 & 17.1 & 79.35 & 15.7 & 82.55 \\
\hline & & $(4.30)^{*}$ & & $(4.19)^{*}$ & & $(4.01)$ & \\
\hline \multirow[t]{2}{*}{$\mathrm{T} 2$} & $0.2 \%$ & 22.33 & 68.98 & 0.0 & 100 & 0.0 & 100 \\
\hline & & $(4.78)$ & & $(0.71)$ & & & \\
\hline \multirow[t]{2}{*}{$\mathrm{T} 3$} & $0.1 \%$ & 0.0 & 100 & 24.33 & 70.62 & 48.5 & 46.11 \\
\hline & & $(0.71)$ & & (4.97) & & (6.99) & \\
\hline \multirow[t]{2}{*}{$\mathrm{T} 4$} & $0.1 \%$ & 4.03 & 94.40 & 11.0 & 86.71 & 31.0 & 65.55 \\
\hline & & $(2.12)$ & & (3.19) & & (5.61) & \\
\hline \multirow[t]{2}{*}{ T5 } & $0.1 \%$ & 0.0 & 100 & 0.0 & 100 & 0.0 & 100 \\
\hline & & $(0.71)$ & & $(0.71)$ & & $(0.71)$ & \\
\hline \multirow[t]{2}{*}{ T6 } & $0.2 \%$ & 7.53 & 89.04 & 0.0 & 100 & 0.0 & 100 \\
\hline & & $(2.83)$ & & $(0.71)$ & & $(0.71)$ & \\
\hline \multirow[t]{2}{*}{$\mathrm{T} 7$} & $0.3 \%$ & 29.33 & 59.26 & 18.0 & 78.26 & 0.0 & 100 \\
\hline & & (5.46) & & $(4.29)$ & & $(0.71)$ & \\
\hline \multirow[t]{2}{*}{$\mathrm{T} 8$} & $0.15 \%$ & 12.90 & 82.08 & 14.0 & 83.09 & 22.5 & 75 \\
\hline & & (3.63) & & (3.18) & & (4.76) & \\
\hline \multirow[t]{2}{*}{ T9 } & $0.3 \%$ & 0.0 & 100 & 0.0 & 100 & 0.0 & 100 \\
\hline & & $(0.71)$ & & $(0.71)$ & & $(0.71)$ & \\
\hline \multirow[t]{2}{*}{ T10 } & $(0.1 \%)$ & 0.0 & 100 & 0.0 & 100 & 0.0 & 100 \\
\hline & & $(0.71)$ & & $(0.71)$ & & $(0.71)$ & \\
\hline \multirow[t]{2}{*}{ T11 } & $(0.2 \%)$ & 0.0 & 100 & 0.0 & 100 & 0.0 & 100 \\
\hline & & $(0.71)$ & & $(0.71)$ & & $(0.71)$ & \\
\hline \multirow[t]{2}{*}{ T12 } & $(0.1 \%)$ & 0.0 & 100 & 0.0 & 100 & 0.0 & 100 \\
\hline & & $(0.71)$ & & $(0.71)$ & & $(0.71)$ & \\
\hline \multirow[t]{2}{*}{ T13 } & & 72.0 & & 82.83 & & 90.0 & \\
\hline & & $(8.45)$ & & (9.12) & & (9.51) & \\
\hline $\operatorname{SEm}( \pm)$ & & 0.24 & & 0.25 & & 0.15 & \\
\hline $\mathrm{CD}(5 \%)$ & & 0.72 & & 0.74 & & 0.45 & \\
\hline
\end{tabular}

*Figures in the parentheses indicates $\sqrt{ }+0.5$ transform values

*T1- Cymoxanil 8\% + Mancozeb 64\% (0.3\%), T2- Propineb (0.2\%), T3- Carbendazim (0.1\%), T4- Thiophanate methyl 70\% (0.1\%),T5- Propiconazole 25\% EC (0.1\%), T6-Hexaconazole 5\% EC (0.2\%), T7- Azoxystrobin 23\% SC $(0.3 \%)$, T8- Difenconazole 25\% EC $(0.15 \%)$, T9- Copper oxy chloride 50\%WP (0.3\%), T10- Carbendazim + Mancozeb WP (0.1\%), T11- Carboxin + Thiram (0.2\%), T12- Tebuconazole $(0.1 \%)$. 
Fig.1a Efficacy of different plant extracts against radial growth of Seed mycoflora- a, b- F. fujikuroi

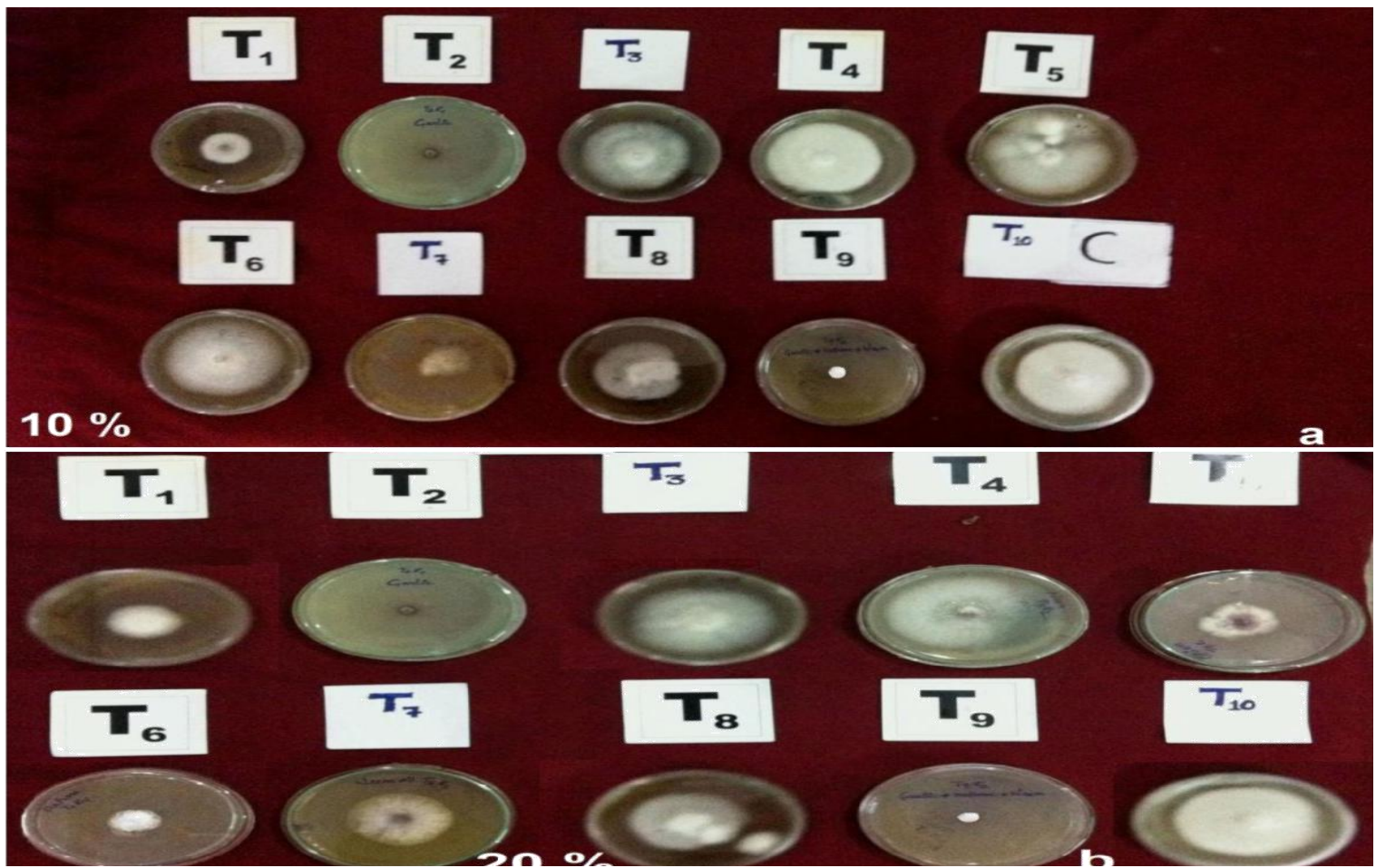

Fig.1b Efficacy of different plant extracts against radial growth of seed mycoflora c, d- C. lunata

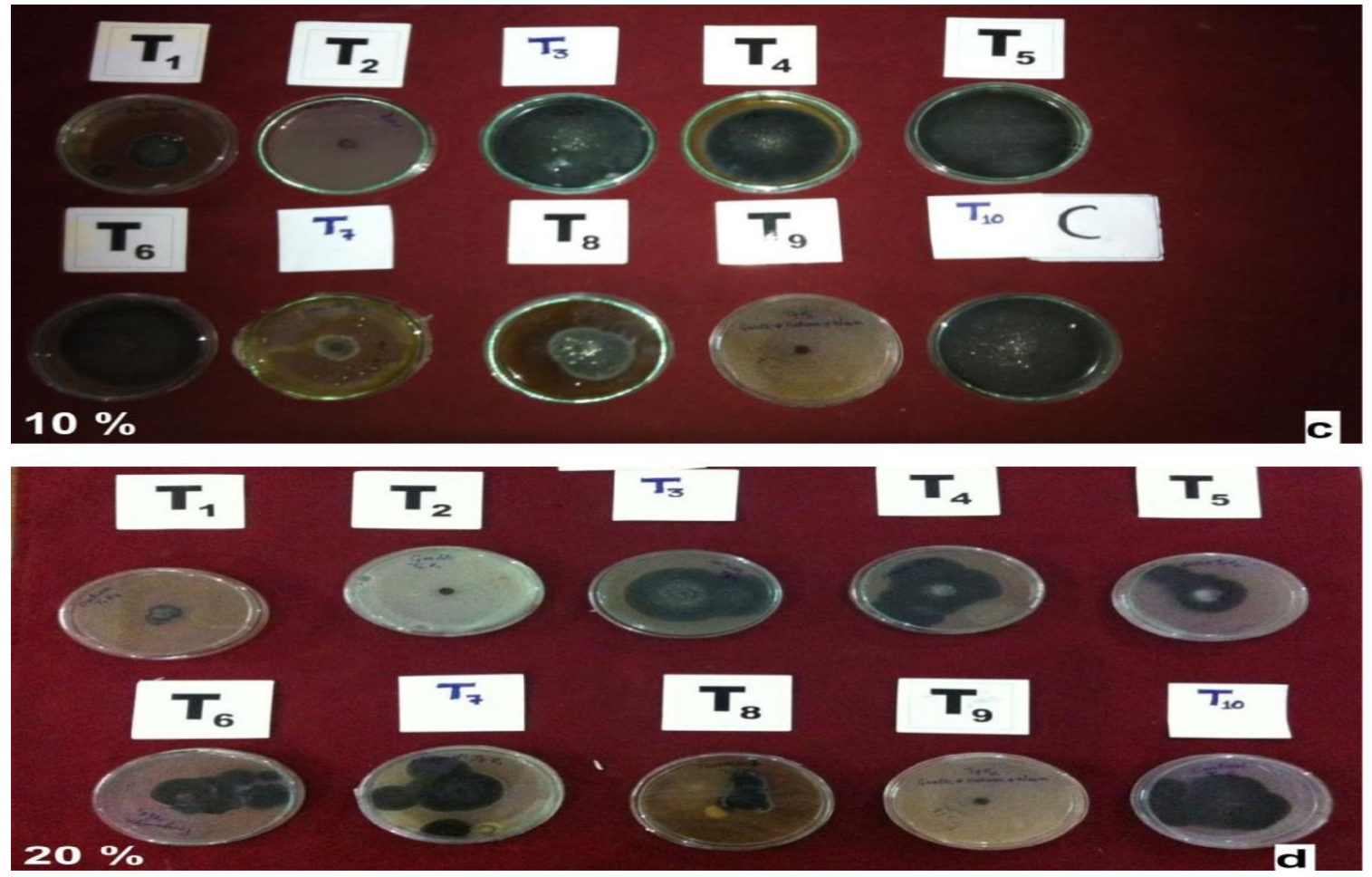


Fig.2 Efficacy of different plant bio-agents against radial growth of different seed mycoflora aF. fujikuroi, b- H. oryzae c- C. lunata

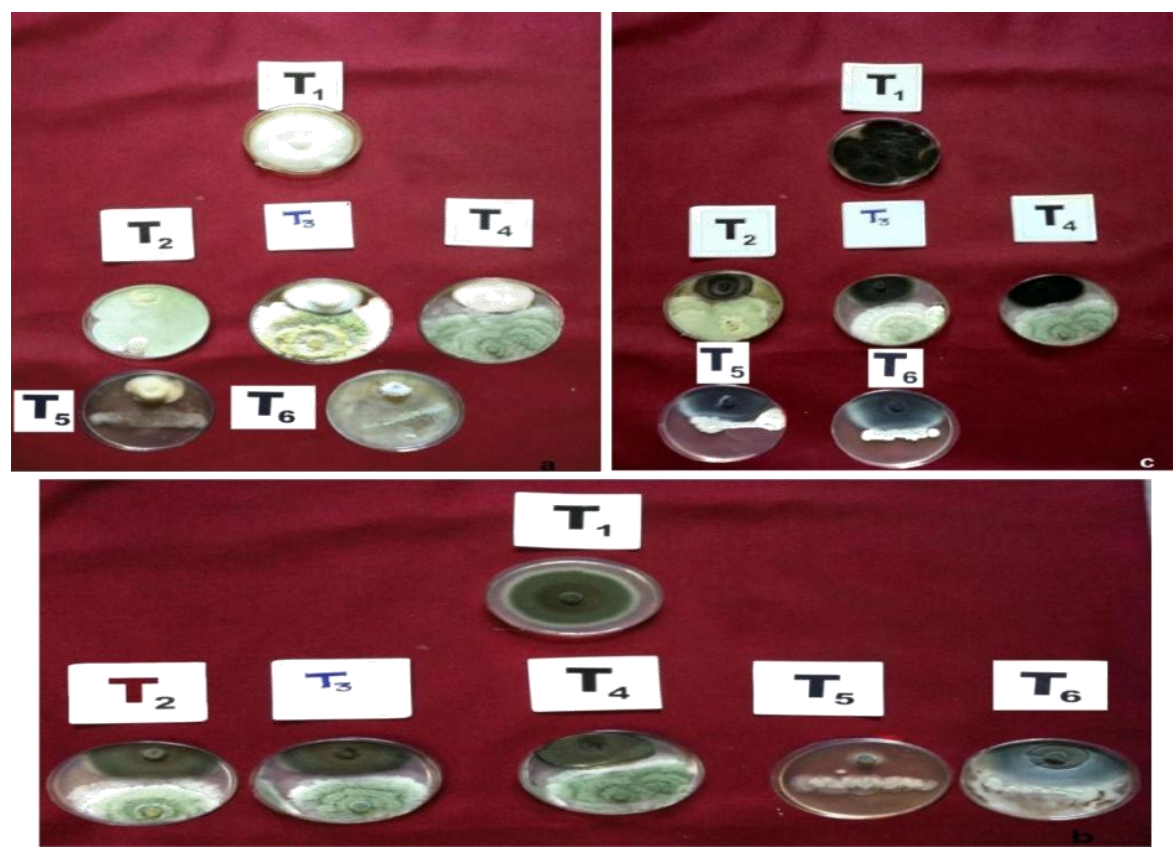

Fig.3 Effect of various chemicals on the radial growth of differnet seed mycoflora $a=F$. fujikuroi, $\mathrm{b}=H$. oryzae, $\mathrm{c}=C$. lunata
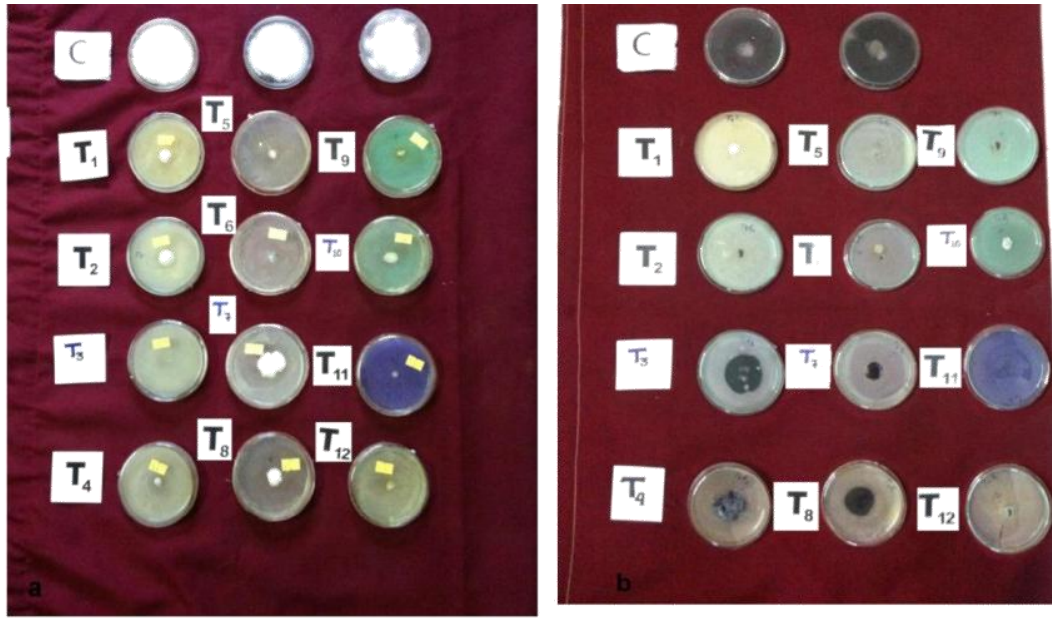

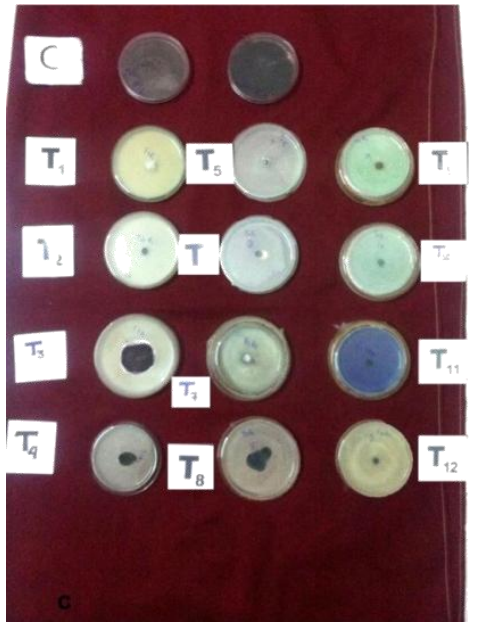

carboxine + thiram $0.2 \%$ and tebuconazole $0.1 \%$ completely inhibited the growth of test pathogens. Thiophenate methyl $0.1 \%$ and difenoconazole $0.15 \%$ exhibited similar reaction against $H$. oryzae and so cymoxanil $8 \%+$ mancozeb $0.3 \%$ and azoxystrobin $0.3 \%$ showing at par reaction (Table 4 and Figure $3 b)$. 


\section{Effect on C. lunata}

Similar trends were also observed in C. lunata as in the above in case of $H$. oryzae. Here Azoxystrobin $0.3 \%$ also induce $100 \%$ growth inhibition of $C$. lunata. Cymoxanil + mancozib $0.3 \%$ was found to the next best fungicides against C. lunata showing $82 \%$ growth inhibition against control (Table 4 and Figure 3c).

A total number of twelve different fungicides were tested against Fusarium fujikuroi, Helminthosporium oryzae and Curvularia lunata for their efficacy. Carbendazim $0.1 \%$, Tebuconazol $0.1 \%$, copper oxychloride $0.3 \%$, Carbendazim+Mancozeb $\quad 0.1 \%$ and Carboxin+Thiram $0.2 \%$ completely inhibited the growth of $F$. fujikuroi. Thiophanate methyl $0.1 \%$ and Hexaconazole $0.2 \%$ also reduced the growth of test pathogen to $94.4 \%$ and $89.4 \%$ respectively Propineb $0.2 \%$, Propiconazol, Hexaconazol $0.2 \%$ copper oxychloride $0.3 \%$, Carboxin+Thiram $0.2 \%$ Carbendazim+Mancozeb $0.1 \%$ and Tebuconazol $0.1 \%$ completely inhibited the growth of $H$. oryzae in in vitro conditions. Butt et al., (2011) reported marked suppression of Helminthosporium sp. by $50 \%$ using Tabesinum, Mancozeb and Curvularia sp. using Topsin $\mathrm{M}$ and mancozeb. The growth of $C$. lunata was also completely inhibited by above fungicides along with Azoxystrobin $0.3 \%$ inducing $100 \%$ growth inhibition, Propineb $0.2 \%$ was less effective against $F$. fujikuroi inducing $68.98 \%$. Similarly Carbendazim was less effective in controlling $H$. oryzae and $C$. lunata. Copper oxychloride $0.3 \%$, Carbendazim+Mancozeb $0.1 \%$ Propiconazol $0.1 \%$, Carboxin+Thiram $0.2 \%$, Tebuconazol $0.1 \%$ were found to be best fungicides imparting $100 \%$ growth inhibition against all the three pathogens.

Nine plant extracts were tested against three pathogens i.e $F$. fujikuroi, $C$. lunata and $H$. oryzae both in 10 and 20 per cent concentration. Garlic bulb extract alone and in combination with datura and neem leaf extract completely inhibited the mycelial growth of all the three pathogens, in both concentration followed by datura leaf extract.

Three species of Trichoderma and bacterial biocontrol agents i.e. Pseudomonas fluorescens, and Bacillus subtilis were tested against $F$. fujikuroi, $H$. oryzae and $C$. lunata in dual culture method. $T$. viride and $B$. subtillis inhibited the growth of $F$. fujikuroi up to $78.11 \%$ and $78.7 \%$ respectively. $P$. fluorescens inhibited $74.06 \%$ radial growth of $H$. oryzae which was more than $B$. subtilis (22.66\% inhibition). $52.4 \%$ growth reduction was found by $T$. viride against $C$. lunata followed by $P$. fluorescens (51.8\% reduction).

Twelve different fungicides were tested against $F$. fujikuroi, $H$. oryzae and $C$. lunata in poison food technique. Propiconazol $0.1 \%$, Carbendazim + Mancozeb 0.1\%, Carboxin + Thiram $0.2 \%$ Tebuconazol $0.1 \%$ and copper oxychloride $0.3 \%$ completely inhibited the growth of all three pathogens. Thiophanate methyl $0.1 \%$ reduced the radial growth of $F$. fujikuroi and $H$. oryzae up to $94.4 \%$ and $86.71 \%$ respectively.

\section{References}

Assadi, P. and Behroozin, M. (1987). The effect of bulb extract of onion and garlic on the mycelial growth of Fusarium spp and Sclerotium ceptorium. Iranian J. Pl. Pathol., 23(1-4): 29-35.

Butt A R, Yaseen S I and Javaid A. 2011. Seed-borne mycoflora of stored rice grains and its chemical control. The Journal of Animal \& Plant Sciences, 21(2): 193-196.

FAO. (2014). Food and Agriculture Organization of the United Nation, XVII, issue No. 3 
Halgekar N Y, Giri G K and Ashwini C. 2014. Efficacy of bio-agents against seed borne fungi of rice. International Journal of Applied Biology and Pharmaceutical Technology, 5: 157158.

IRRI. 2006. Bringing hope, improving lives: Strategic Plan 2007-2015. Manila.61 p.

Lalitha V, Kiran B and Raveesha K A. 2014. Identification of potentiality of essential oils of Piper nigrum L. (Berry) and Santalum album L. (Wood) for antifungal activity against seed borne fungi of paddy. International Journal of Pharmacy and Natural Medicines, 2 (2): 136-139.
Selvaraj K and Annamalai P. 2015. In vitro evaluation of fungicides and two species of Trichoderma against Sarocladium oryzae causing sheath rot of paddy (Oryza sativa L.). World Journal of Pharmaceutical Research, 4: 1200-1206.

Srinivas P and Ramakrishnan G. 2005. Management of rice seed borne pathogens by native bio-agents. Ann. Plant Protection Science, 13 (2): 422426.

Vincent JM. 1947. Distortion of fungal hyphae in the presence of certain inhibitors, Nature 15: 850-850

\section{How to cite this article:}

Mohammad Waris, Pagoti Hemalatha, M.K. Mishra and Abhaya Kumar Kar. 2018. Management of Seed Borne Pathogens of Rice. Int.J.Curr.Microbiol.App.Sci. 7(10): 36383648. doi: https://doi.org/10.20546/ijcmas.2018.710.421 